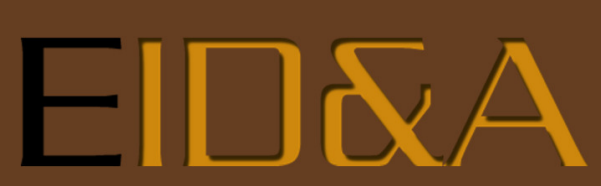

Revista Eletrônica de Estudos Integrados em Discurso e Argumentação

http://dx.doi.org/10.17648/eidea-13-1526

\title{
POR UMA ANÁLISE DISCURSIVA E ARGUMENTATIVA DA POLÊMICA ii
}

\author{
Ruth Amossyiii
}

Resumo: Partindo do pressuposto de que análise do discurso e a argumentação retórica se combinam e se completam para explorar, simultaneamente, o funcionamento verbal do discurso polêmico e suas funções sociodiscursivas (AMOSSY, 2012 [2000]; AMOSSY, 2012), este artigo visa discutir a singularidade do discurso polêmico (AMOSSY, 2014) e refletir acerca de sua inscrição no quadro do debate público. Considerando que as mídias sempre destacam novas polêmicas em torno dos temas sociais mais distintos, examinaremos aqui o caso da polêmica que se desenrolou no jornal Libération em torno das declarações de Bernard-Henri Levy, sobre o episódio da flotilha turca abordada por Israel em 29 de maio de 2010. Por fim, aponta que a polêmica não levou as duas partes a um acordo, mas cumpriu uma importante função social, pois enseja uma confrontação pública em que cada um dos dois campos pode expressar sua dissenção com base em valores comuns, fortalecendo a demoracria.

Palavras-chave: Polêmica. Discurso. Argumentação. Mídia. Democracia.

Abstract: We assume, in this paper, that Discourse Analysis and Rhetorical Argumentation combine and complete themselves in order to simultaneously explore the verbal functioning of the polemical discourse and its socio-discursive functions (AMOSSY, 2012 [2000]; AMOSSY, 2012). Thus, we aim to discuss the singularity of the polemical discourse (AMOSSY, 2014) and reflect over its inscription in the public debate dimension. Considering that the media always highlights new polemics over distinct social themes, we examine here the polemics developed in the newspaper Libération over the declarations made by Bernard-Henri Levy about the Turkish flotilla raided by Israel on May $29^{\text {th }}, 2010$. Lastly, we point out that the polemics itself didn't lead the two sides to an accord, but played an important social function, insofar as it staged a public confrontation in which each of the two fields could express their dissension based on common values, strengthening democracy.

Keywords: Polemics. Discourse. Argumentation. Media. Democracy.

\footnotetext{
'Artigo originalmente publicado em: AMOSSY, Ruth. Pour une analyse discursive et argumentative de la polemique. In: PIRIS, Eduardo Lopes; FERREIRA, Moisés Olímpio. Discurso e Argumentação em múltiplos enfoques. Coimbra: Grácio Editor, 2016. 113-128.

ii Dando seguimento a uma pesquisa global sobre o discurso polêmico na esfera democrática efetuada sob a égide da Fundação Israelense de Ciências (ISF, projeto 734/08), o presente trabalho foi realizado no âmbito de um projeto de pesquisa da Israel Science Foundation sobre "A deslegitimação de Israel”: os usos políticos e retóricos de uma fórmula na França (projeto 186/12, sob a responsabilidade de Ruth Amossy e Denis Charbit).

iii Professora Emérita da Universidade de Tel Aviv, Israel. Coordenadora do grupo de pesquisa ADARR - Analyse du Discours, Argumentation et Rhétorique. E-mail: amossy@bezeqint.net.
} 
EID\&A - Revista Eletrônica de Estudos Integrados em Discurso e Argumentação, Ilhéus, n. 13, jan/jun.2017.

\section{Introdução}

Combinar as práticas que tiveram origem na análise do discurso e na argumentação retórica ${ }^{1}$ permite responder às indagações que a polêmica suscita sempre: qual é a natureza do discurso polêmico, o que o torna singular? Mas também: como a polêmica, com sua veemência, se inscreve no quadro do debate público, em que medida ela se afasta de suas normas declaradas, quais são seus objetivos e suas implicações? Em resumo, trata-se de definir a polêmica como fenômeno verbal, de ver como ela funciona, e verificar que papéis é chamada a desempenhar no espaço público contemporâneo.

Essas indagações se colocam no cenário do que pode parecer um enigma. De fato, trata-se de um modo de discurso frequentemente desprezado por seus excessos (sua violência, sua paixão, sua tendência aos extremos). E, no entanto, continua a se impor, e mesmo a se fortalecer e a frutificar. Todo mundo parece concordar ao depreciar a polêmica, muitas vezes excluída dos limites do debate democrático² que, na opinião geral, deve ser racional, equilibrado e buscar o acordo. Ao mesmo tempo, as mídias não cansam de destacar novas polêmicas em torno dos mais diferentes temas sociais, de tal modo que o fato de ser censurado não impede em nada a propagação do fenômeno. É certo que cada um se coloca fora da prática polêmica, ao mesmo tempo em que acusa os outros de fazê-lo. $O$ que não impede que os polemistas continuem a se fazer ouvir sobre todos os problemas de sociedade - o casamento para todos, a imigração, as medidas econômicas do governo Hollande, e muitos outros temas menos centrais, objetos de dissensões mais ou menos fortes. A condenação que atinge o tratamento polêmico desses assuntos não parece afetar tal prática.

Essa constatação leva a examinar com mais detalhes a polêmica pública, não só para melhor compreender sua natureza, mas também para destacar suas funções sociais e políticas. Se um fenômeno verbal subsiste ao longo dos anos apesar das inúmeras críticas que desperta, é porque preenche determinadas funções, nem sempre visíveis, mas não menos necessárias. Em vez de fazer parte do coro das censuras virtuosas, é necessário tentar delinear essas funções. Nessa perspectiva, trata-se de ligar a questão da forma

\footnotetext{
${ }^{1}$ A este respeito, consute-se Amossy 2012 (2000) e Amossy 2012.

2 "Seus detratores o condenam essencialmente por recorrer a formas de violência incompatíveis com o bom funcionamento da vida social [...] e por privar o auditório de sua liberdade de pensar": é uma "degradação dos diálogos” (KOREN, 2003, p. 71)
} 
EID\&A - Revista Eletrônica de Estudos Integrados em Discurso e Argumentação, Ilhéus, n. 13, jan/jun.2017.

discursiva e da função social numa mesma indagação: como a maneira pela qual o discurso polêmico se constrói na sociedade contemporânea permite melhor definir o papel (ou os papéis) que aí desempenha? Tal era a motivação do livro lançado em 2014, Apologie de la polémique [Apologia da polêmica], que tem como objeto continuar e sistematizar os trabalhos fecundos elaborados sobre a polêmica até então³.

É neste ponto de confluência que se pode ver em que a análise do discurso e a argumentação retórica se combinam e se completam para explorar, ao mesmo tempo, o funcionamento verbal do discurso polêmico e suas funções sociodiscursivas. Em ambas, estamos no domínio do discurso, a saber, do uso que os sujeitos falantes fazem da língua em contexto. É precisamente este uso que se deve descrever para compreender seus mecanismos internos. Em outros termos, o analista do discurso e o retórico procuram evidenciar as regras que modelam a troca verbal em enquadres previamente regulados, e oferecer os instrumentos que permitam dar conta de um corpus específico. Podem ser trocas conversacionais privadas, discurso político ou jurídico, trocas profissionais, de comunicação via internet... Cada um desses tipos ou desses gêneros de discurso possui seus próprios enquadres e suas próprias modalidades. É fato que, quando se confronta a abordagem do analista do discurso e a do retórico, constata-se que o primeiro privilegia as restrições às quais se submete a fala individual: ele destaca o fato de que ela se dá necessariamente num sistema institucional, dóxico e cultural que a modela em parte, mesmo quando se acredita que é livre e espontânea. Quanto ao retórico, ele se interessa pelas estratégias verbais que permitem aos seres humanos controlar o logos, que é, ao mesmo tempo, palavra e razão, para debater assuntos controversos, buscando conquistar a adesão do auditório. Ao insistir no esforço de persuasão, ele insiste mais sobre a agentividade do sujeito falante, seu poder de agir livremente graças à arte do discurso. Mas, em ambos os casos, trata-se de trocas verbais, e, sendo assim, de agir sobre o mundo circundante ao agir sobre o outro. Para o analista do discurso tanto quanto para o retórico, dizer é fazer. Ambos se interrogam sobre a maneira pela qual diferentes práticas discursivas permitem gerir as relações humanas e os interesses públicos. A esse respeito, a questão que se coloca é: como esses interesses podem ser gerenciados pelo exercício de uma

3 E particularmente, Angenot (2002), Garand (1998), Kerbrat-Orecchioni (1980), Kock (2009), Phillips (1996), para citar os mais conhecidos. 
EID\&A - Revista Eletrônica de Estudos Integrados em Discurso e Argumentação, Ilhéus, n. 13, jan/jun.2017.

palavra da desmedida, cuja etimologia (polemos) a torna semelhante a uma guerra verbal?

\section{Uma retórica do dissenso: anatomia da polêmica}

Partiremos, aqui, da argumentação retórica, na medida em que ela busca o quadro de reflexão no qual a questão da polêmica recebe sua significação plena. É fato que a retórica originária de Aristóteles acentua a busca do consenso. Este é o principal objetivo do orador, segundo essa retórica: levar seu auditório a compartilhar suas concepções, a fim de poder tomar decisões coletivas que conduzam a ações aprovadas pela maioria.

Nessa perspectiva, a busca do acordo é privilegiada. Na ausência de uma verdade cientificamente demonstrável que não existe nas relações humanas, é preciso, com efeito, que a maioria consiga concordar sobre uma solução que Ihe pareça aceitável. Trata-se então do domínio do razoável (PERELMAN, 1979), que difere do racional, que é visto como um conjunto de procedimentos que conduz a uma solução matematicamente demonstrável. Isso significa que é preciso escolher entre algumas opções, selecionando aquela que pareça a mais plausível e a mais apta a assegurar o bem comum. Situando-se na grande tradição aristotélica, Perelman \& Olbrechts-Tyteca (1970 [1958]) falam de adesão do espírito a uma tese submetida à sua aprovação. A importância central conferida ao acordo pela retórica é típica do pensamento democrático que the deu origem. As dissensões persistentes são consideradas como perturbações à harmonia social e entraves ao processo de tomada de decisão. Daí decorrem as inúmeras condenações à polêmica, isto é, ao choque muitas vezes brutal de opinióes contraditórias que acentuam as diferenças em vez de procurar um consenso viável voltado para a ação comum. Enquanto, de um lado, o debate é necessário, porque permite uma troca de opiniões divergentes sobre uma mesma questão que pretende chegar a um acordo da maioria, por outro lado, a polêmica aparece como supérflua, e mesmo nociva, na medida em que parece buscar o dissenso, e não o consenso.

A polêmica seria uma degradação infeliz do debate público no qual se fundamenta a democracia? É o que parecem indicar as definições correntes do fenômeno, encontradas na metalinguagem de amostras significativas da imprensa. Segundo Nadine Gelas (1980), Christian Plantin (2003) e Roselyne Koren (2003), que analisaram o que os jornais dizem da polêmica, ela é definida como uma palavra de paixão e de violência que procura assassinar o 
EID\&A - Revista Eletrônica de Estudos Integrados em Discurso e Argumentação, Ilhéus, n. 13, jan/jun.2017.

adversário, privar o público de sua liberdade de pensamento e degradar as trocas. Em resumo, a polêmica é coercitiva e estéril, não chegando a uma solução, não participando da argumentação raciocinada em busca de concordância.

Essa definição daria conta, efetivamente, da real natureza do discurso polêmico? É uma questão à qual as ciências da linguagem podem nos ajudar a responder, pois nos fornecem os instrumentos com os quais é possível examinar a natureza do discurso polêmico a partir de corpora concretos. Além disso, cabe indagar: a polêmica desempenha, na vida pública, o papel funesto que the atribuem? Impõe-se uma reavaliação de suas funções retóricas, e também da função do dissenso na democracia, para melhor compreender o que está em jogo na polêmica. Estamos então no centro da argumentação retórica. Seria um equívoco, entretanto, separar essas duas questões e essas duas disciplinas. De fato, a definição da polêmica verbal está inserida na retórica: trata-se de saber se participa ou não da argumentação, e em caso afirmativo, em que medida e segundo quais modalidades. A questão das funções da polêmica na democracia não é estranha à análise do discurso, que examina o discurso no entrecruzamento do formal com o social, em suas determinações sociais, institucionais e políticas.

Retomemos então a definição do discurso polêmico, que Catherine Kerbrat-Orecchioni expôs num excelente artigo de 1980. É um discurso fortemente dialógico: responde à palavra do outro, mesmo quando escolhe não nomeá-lo. Entretanto, sempre o faz para se opor ao outro - Angenot fala, a esse respeito, de anti-discurso (1982). Para desqualificar o discurso do outro, a polêmica recorre a um conjunto de procedimentos discursivos e retóricos: a negação, os jogos sistemáticos de oposição, a marcação axiológica (avaliação em termos de Bem/Mal), a reformulação, o manejo direcionado do discurso relatado, a ironia, a hipérbole etc. Todas as armas são boas para o combate. Entretanto, Kerbrat-Orecchioni (1980) coloca como traço definidor essencial o descrédito lançado sobre o outro: a polêmica que visa o discurso do outro é, antes de mais nada, uma palavra de desqualificação. Além disso, muitas vezes o ataque não visa somente ao discurso do adversário, mas também à sua pessoa. Recorre-se então ao argumento ad hominem, que é considerado um paralogismo, um argumento falacioso. Este tem a ver com a violência verbal na medida em que põe em causa o locutor individual ao mesmo tempo que 
EID\&A - Revista Eletrônica de Estudos Integrados em Discurso e Argumentação, Ilhéus, n. 13, jan/jun.2017.

suas declarações (por vezes, põe em causa o locutor mais do que suas declarações).

Todos esses elementos, entretanto, não são suficientes para definir a especificidade do discurso polêmico. De fato, basicamente, este se define como confronto de teses antagonistas. Enquanto tal, diz respeito à argumentação - a tal ponto, aliás, que Plantin (2003) chegou a se perguntar em que este discurso difere de uma argumentação comum, uma vez que esta consiste justamente no confronto de respostas que se opõem, a respeito de uma mesma questão - num debate que nasce de uma divergência de visões sobre um assunto de interesse público. Nesse debate sempre se encontram um Proponente, um Oponente e um Terceiro. Curiosamente, a polêmica, que muitas vezes é excluída do "reino" da argumentação, aparece nessa perspectiva como uma forma argumentativa difícil de se distinguir das outras. Qual é então sua especificidade?

É, para começar, a dicotomização, estudada e posta em evidência por Marcelo Dascal em sua teoria das controvérsias (1998). De fato, para que haja polêmica, é necessário que as respostas antagônicas sejam apresentadas como duas opções antitéticas que se excluem mutuamente. Nos termos de Dascal (2008, p. 34), é "radicalizar uma polaridade acentuando a incompatibilidade dos polos e a inexistência de alternativas intermediárias, destacando o caráter evidente da dicotomia tanto quanto o polo que deve receber a preferência". Em resumo: é branco ou preto, e o polemista insiste na boa escolha a fazer em tal circunstância. É essa oposição radical que diferencia a polêmica do debate contraditório onde as opções divergentes são postas à prova da discussão.

Ora, a dicotomização tem um efeito sociodiscursivo. Ela produz uma polarização - não como operação quase-lógica, mas como agrupamento em dois campos antagonistas que desenvolvem uma hostilidade mútua. A polarização coloca um "nós" diante de um "eles", e tem sido bem estudada pela retórica dos movimentos sociais (ORKIBI, 2008). Assim, King \& Anderson (1971, p. 244) a definem como "um processo através do qual um público extremamente diversificado se separa em dois [...] grupos fortemente contrastados e mutuamente excludentes, compartilhando uma grande solidaridade para com [certos] valores" considerados fundamentais.

Isso significa que a polarização tem implicações identitárias. Trata-se de se aliar a um grupo constitutivo de uma identidade, ou suscetível de reforçá-la. 
EID\&A - Revista Eletrônica de Estudos Integrados em Discurso e Argumentação, Ilhéus, n. 13, jan/jun.2017.

Quanto mais a adesão a uma determinada tese é constitutiva de uma identidade compartilhada, mais o indivíduo tenderá a apegar-se a ela: a maneira pela qual percebe a si mesmo, a maneira pela qual os outros o veem e a medida em que participa fortemente de uma comunidade, é que estão em jogo. Encontramo-nos então numa lógica de divisão social, de defesa identitária e de combate pelo triunfo dos valores e opções de seu grupo.

Retomemos os elementos definidores aqui reunidos. Discurso dialógico que se apresenta sob a forma de anti-discurso, a polêmica se caracteriza pela dicotomização, pela polarização, e pelo descrédito à tese ou à pessoa do outro. Ela pode (mas não deve) ser acompanhada de paixão. A hostilidade entre grupos antagonistas se presta a isso, mas o tratamento emocional não é obrigatório e em caso algum, suficiente para definir a polêmica como tal. 0 mesmo acontece com a violência verbal. $O$ confronto antagonista de posições apela muitas vezes - mas não necessariamente - para a violência verbal. Existem enquadres institucionais em que tal violência não é admissível, e em que a polêmica a dispensa; existem estratégias fortemente polêmicas que evitam usar de violência verbal, sobretudo em suas formas insultantes.

De todo modo, é conveniente voltar ao início desse percurso, considerando-se o fato de que o polêmico, longe de situar-se fora do domínio da argumentação, faz intimamente parte dele. Pode-se dizer que a argumentação é um continuum, em cujo centro se encontra o debate racional de duas teses divergentes, e que, em suas duas extremidades, tem-se: de um lado, o discurso que não menciona a opção que está atacando, para se concentrar naquela que quer valorizar, e do outro lado, o choque das posições antagonistas. $O$ polêmico (utilizo este termo em seu sentido genérico, do mesmo modo que se diz "o político") se situa num dos polos deste continuum. Enquanto tal, representa uma modalidade argumentativa legítima. $O$ fato de que a dicotomização e a polarização não favoreçam a busca de um acordo não muda nada. Eu diria mais: o fato de a polêmica ser uma modalidade argumentativa leva certamente a repensar a natureza da retórica e a centralidade dada à persuasão. E se a argumentação retórica não fosse somente destinada a persuadir? E se o acordo não fosse o único objetivo da discussão democrática - se o dissenso também tivesse virtudes e funções no espaço democrático? 
EID\&A - Revista Eletrônica de Estudos Integrados em Discurso e Argumentação, Ilhéus, n. 13, jan/jun.2017.

\section{Análise de uma polêmica midiática: BHL e Joffrin sobre a "deslegitimação de Israel"}

Pretendemos abordar essas questões a partir de exemplos concretos. Examinaremos aqui o caso da polêmica que se desenrolou no jornal Libération em torno das declarações de Bernard-Henri Levy (BHL), famoso intelectual francês, sobre o episódio da flotilha turca abordada por Israel em 29 de maio de 2010. Sabe-se que BHL é um filósofo e um personagem midiático muito engajado em diversas causas políticas (ele interveio nos conflitos da Bósnia e do Afeganistão, entre outros), e também bastante controverso, tanto pela sua obra quanto por seu ativismo político.

Recordemos rapidamente o episódio no qual BHL intervém. Trata-se da abordagem de um navio pela marinha israelense, o Mavi Marmara, que fazia parte de uma flotilha turca pró-palestina que procurava quebrar o bloqueio imposto por Israel à faixa de Gaza, governada pelo Hamas, uma organização definida como terrorista, para impedir a passagem de armas e de materiais que serviam para fabricar armas. A flotilha, que se chamava Free Gaza, transportava ajuda humanitária e materiais de construção, e havia recusado passar sua carga (como havia sido proposto) pelo porto de Ashdod. Os soldados foram atacados quando houve a abordagem de um dos navios, $\mathrm{o}$ Mavi Marmara, e reagiram; o incidente resultou em 9 mortos e 28 feridos e causou furor nas mídias internationais. A comissão de inquérito Palmer da ONU, de 2 de setembro de 2011, considerou legal o bloqueio marítimo a Gaza, justificando assim a interceptação da flotilha como uso da força "com fins de legítima defesa", visto que os militares "foram recebidos por uma resistência organizada e violenta de um grupo de passageiros"; todavia, o procedimento israelense de abordagem do navio foi considerado "excessivo e irrazoável" e o número de vítimas considerado "inaceitável".

BHL escreve imediatamente na revista que ele dirige, La règle du jeu [A regra do jogo] um artigo intitulado "O autismo não é uma política" (31.05.2014) onde critica e deplora a abordagem do navio e suas consequências. Os artigos que tratam do episódio se multiplicam na imprensa, e o jornal Libération traz a seguinte manchete em $1^{\circ}$ de junho de 2010: 


\title{
Figura 1-Manchete de $1^{\circ}$ de junho de 2010 do Libération
}

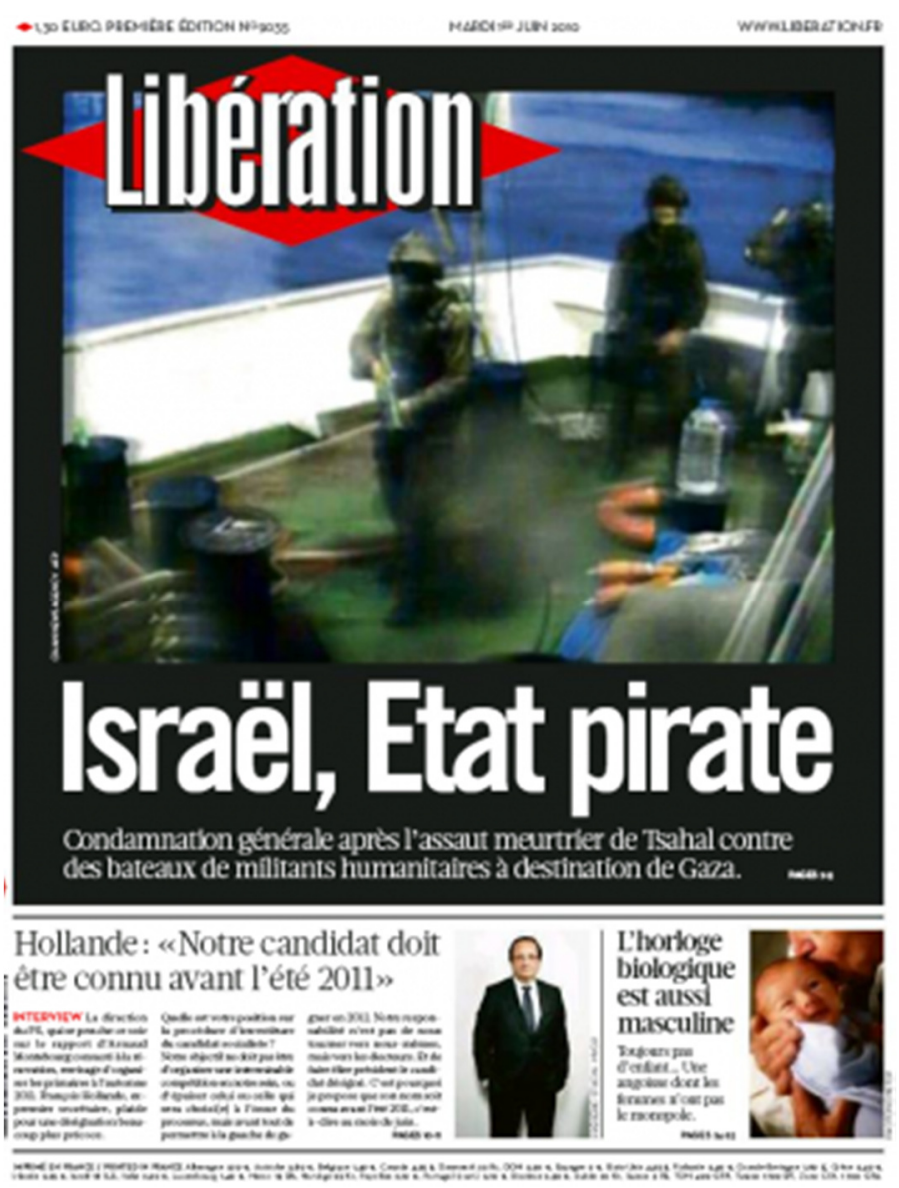

Em 5 de junho, aparecia nesse mesmo jornal um editorial de Laurent Joffrin, redator chefe, intitulado "Indignação", em que chamava o bloqueio de "total e impiedoso", declarando:

\begin{abstract}
A operação israelense estava fora de qualquer fundamento legal; ela prolongava um bloqueio que atinge cruelmente a população civil de Gaza. Assim a indignação provocada pela morte de nove pessoas está longe de se explicar somente pela hostilidade costumeira a Israel que domina em uma parte do mundo. Ela é sincera [...]
\end{abstract}

BHL, acionista do Libération, publica então, em 7 de junho, um longo artigo nas páginas desse jornal intitulado: "Porque eu defendo Israel”. Ele se coloca contra o que chama de "desinformação" - um termo que ele repete, em anáfora insistente, no início de cada parágrafo e mesmo em início de frase. Ele ataca o Libération, que colocou em primeira página um artigo intitulado "Israel, Estado pirata", e também Joffrin por ter falado de "bloqueio total e impiedoso". No mesmo número, Joffrin publica um artigo 
EID\&A - Revista Eletrônica de Estudos Integrados em Discurso e Argumentação, Ilhéus, n. 13, jan/jun.2017.

"Para responder a BHL", no qual rejeita as condenações de seu oponente e justifica sua própria posição.

Irei me concentrar aqui mais particularmente na polêmica que se desenvolve em torno da noção de "deslegitimação de Israel” descrita por BHL para acusar os detratores de Israel. Examine-se, a esse propósito, a passagem seguinte:

Desinformação: o silêncio, na França como em outros lugares, sobre a inacreditável atitude do Hamas que, agora que a carga da flotilha cumpriu sua função simbólica, agora que ela permitiu colocar a culpa no Estado judeu e relançar como nunca a mecânica de sua diabolização (também no Libération, aquela manchete terrível que, se as palavras ainda querem dizer alguma coisa, só pode apontar para o sentido da deslegitimação do Estado hebreu: "Israel, Estado pirata"), agora que, em outros termos, são os Israelenses que, uma vez feita a inspeção, entendem encaminhar a ajuda a seus supostos destinatários - o silêncio que se faz então, sobre a atitude de um Hamas bloqueando a dita ajuda no check point de Kerem Shalom e deixando-a lentamente apodrecer: ao diabo as mercadorias passadas entre as mãos dos agentes alfandegários judeus! Que vão para o lixo os "brinquedos" que fizeram chorar as almas boas dos europeus mas que se tornaram impuros pelas longas horas passadas no porto israelense de Ashdod! Para a gangue de islamitas que tomaram o poder pela força há três anos, as crianças gazenses não são nada mais que escudos humanos, bucha de canhão ou vinhetas midiáticas, suas brincadeiras e desejos são a última coisa com que as pessoas se importam - mas quem diz isso? Quem fica indignado? Quem se arrisca a explicar que se existe, em Gaza, um sequestrador, um frio aproveitador sem escrúpulos do sofrimento das pessoas, e, em particular, das crianças, resumindo, um pirata, não se trata de Israel mas do Hamas? (grifos meus).

O texto é claramente dialógico: ele retoma o essencial dos comentários midiáticos, e mais particularmente os do Libération, sob o termo de "desinformação", que não aponta simplesmente erros de fatos, mas denuncia apresentações deliberadamente e complacentemente falsas, truncadas e enganadoras. BHL retoma mais precisamente os ataques lançados contra Israel e se apodera de termos-chave: uma citação entre aspas da manchete "Israel, Estado pirata" acompanhada de comentários axiológicos: "a manchete terrível"; a utilização da qualificação de pirata em "resumindo, um pirata, não se trata de Israel, mas do Hamas". O mesmo procedimento de retorsão é efetuado na retomada do termo "indignação", o título do editorial de Joffrin, usado dessa vez em relação às ações do "Hamas": "Quem fica indignado?". Esses ataques são dirigidos tanto ao Oponente escolhido como alvo, quanto ao Terceiro, os leitores que se imagina reconhecerem como bem fundamentada a posição de BHL. 
EID\&A - Revista Eletrônica de Estudos Integrados em Discurso e Argumentação, Ilhéus, n. 13, jan/jun.2017.

Ele lança o Oponente no descrédito: trata-se claramente de uma acusação formulada em termos virulentos que ataca a ética dos comentaristas e das mídias, como o mostram os axiológicos negativos e a hipérbole do enunciado que menciona uma "onda de hipocrisia, de má fé e, no final das contas, de desinformação". Embora ninguém seja visado pessoalmente, já que se trata de um fenômeno generalizado, esboça-se um Oponente sob a figura dos formadores de opinião para os quais toda ocasião é boa para denegrir Israel: "A onda [...] de desinformação" [...] "parecia só esperar esse pretexto para, como a cada vez que o Estado judeu comete um erro e tropeça, mergulhar nessa brecha e desembocar nas mídias do mundo inteiro". BHL designa então um adversário malévolo cujos ataques são repetidos e quase obsessivos (a cada vez que...), que não são baseados em razões sólidas mas em "pretextos", e age de maneira excessiva e desproporcional ("desembocar nas mídias do mundo inteiro"). Nesse enredo, Israel, sem dúvida, é culpado, entretanto é vítima de uma hostilidade sistemática, excessiva e injustificada.

Encontramo-nos diante de um discurso polêmico: ele dicotomiza (a verdade sobre Israel versus a desinformação), polariza (os adversários encarniçados de Israel contra seus defensores) e desqualifica o adversário, num estilo impregnado de pathos (as proposições exclamativas que traduzem a emoção do locutor, os apelos à indignação e à piedade pelas crianças transformadas em bucha de canhão pelo Hamas...).

A polêmica, em parte, gira em torno do argumento da "deslegitimação" e da "diabolização de Israel", e eu gostaria de me deter um pouco nessa questão. Segundo BHL, a operação da flotilha turca era uma "armadilha tática e midiática armada contra Israel pelos provocadores de Free Gaza". "[...] ela permitiu surpreender o Estado judeu em falta e relançar como nunca a mecânica de sua diabolização". Trata-se de "relançar", logo, é um fenômeno preexistente que traz em si sua "mecânica", um conjunto de operações suspeitas destinadas a apresentar Israel como o representante do Mal. Notese que o texto utiliza nesse trecho a perífrase "o Estado judeu" que comporta um traço definidor de Israel: assim reunidos, estado "judeu” e diabolização ativam uma rica memória discursiva que remete a um antissemitismo secular (os judeus, assassinos do Cristo, e figura religiosa do Mal; os judeus como bodes expiatórios, causa do Mal através dos tempos, cujo ápice levou ao nazismo). O pressuposto é que a hostilidade midiática para com Israel está ligada ao ódio aos judeus, que sempre procura uma ocasião para se 
EID\&A - Revista Eletrônica de Estudos Integrados em Discurso e Argumentação, Ilhéus, n. 13, jan/jun.2017.

manifestar. Neste ponto, o polemista ataca os detratores, que são "provocadores" agindo para diabolizar seu alvo, para transformá-lo numa entidade com a qual não convém dialogar (não se fala com o Diabo) e que se deve maldizer e isolar.

Ora, a qualificação de Estado pirata (um estado que está fora da lei e que exerce uma violência criminosa semelhante àquela que exercem os piratas contra os navios para saquear e massacrar) não remete apenas à diabolização como Mal religioso e moral. Essa qualificação também traz a fórmula de "deslegitimação", dessa vez do Estado hebreu, uma outra perífrase - em que não é mais o judaísmo em sua relação com o antissemitismo que se põe em evidência. Falo de "fórmula" no sentido dado a esse termo por Alice Krieg-Planque (2009): uma expressão largamente difundida, que se torna uma menção obrigatória para tratar de um determinado assunto, traz em si implicações sociais e políticas importantes, e dá lugar a interpretações diversas que a tornam polêmica. Efetivamente, "deslegitimação de Israel" tornou-se uma fórmula no discurso israelense como naquele dos pró-Israelenses. Globalmente, designa e denuncia a tentativa de privar o Estado de Israel de sua legitimidade para melhor combatê-lo numa guerra de imagem, e conseguir isolá-lo para, no final das contas, erradicá-lo. Israel é metaforicamente apresentado como Estado pirata porque abordou um navio no mar. Ora, o pirata é, por definição, fora da lei, ele não pode reivindicar nenhuma legalidade (em suas ações de banditismo e de assassínio, ele transgride todas as leis), e não tem nenhuma legitimidade (não tem apoio em nenhum direito natural). Assim, BHL acusa seus adversários de solapar a legitimidade de um Estado, a mesma que lhe confere o direito à existência e um lugar no concerto das nações. Ele os acusa, além disso, de cometer uma violência simbólica grave em relação ao único Estado democrático da região, ao declarar seu apoio aos regimes ditatoriais e aos grupos terroristas, pondo assim em perigo os valores do Ocidente, e mais particularmente os da esquerda:

Confusão de uma época em que se combatem as democracias como se se tratasse de ditaduras ou de Estados fascistas. É de Israel que se trata nesse turbilhão de ódio e de loucura - mas é também, o que é preocupante, de algumas das aquisições mais preciosas, à esquerda principalmente, do movimento das ideias dos últimos trinta anos, que se acham em perigo. Aquele que tem ouvidos para ouvir, ouça. 
EID\&A - Revista Eletrônica de Estudos Integrados em Discurso e Argumentação, Ilhéus, n. 13, jan/jun.2017.

Laurent Joffrin assume a tarefa de responder no mesmo número do Libération, para repercutir o que BHL escreve e engajar-se com ele numa troca polêmica onde tenta ganhar vantagem ao temperar os impulsos passionais e a violência verbal. Não se trata mais do movimento de indignação do editorial que tinha por título: "Indignação". Num primeiro momento, Joffrin confessa que o bloqueio não é total; mas mantém o qualificativo "impiedoso". Recorre a um argumento de autoridade, que é também um argumento mais forte: aqueles que compartilham desta opinião "não são obrigatoriamente inimigos de Israel" - e cita a Casa Branca, o jornalista israelense Gideon Levy, editorialista do Haaretz, jornal diário israelense ("que fala 'de um confisco ineficaz, ilegal e contrário à moral”"), ou ainda o trabalhista israelense Isaac Herzog (é necessário "facilitar as condições da população e achar alternativas de segurança confiáveis em vez do bloqueio"). Retorna assim ao argumento de seu primeiro editorial, que BHL havia desconsiderado:

Assim a indignação provocada pela morte de nove pessoas está longe de remeter somente à hostilidade de princípio a Israel que se verifica numa parte do mundo. Ela é sincera e se baseia principalmente num raciocínio que leva em conta a legítima necessidade de segurança que mobiliza os Israelenses.

Esse contra-ataque não é apenas uma defesa de suas posições e de seu jornal, mas um questionamento radical da atitude que consiste em acusar de antissemitismo todos os que criticam o Estado de Israel. Inscreve-se num espaço polêmico onde o Oponente acusa os pró-Israelenses de censurar toda crítica política ao interpretar as condenações feitas ao governo israelense como preconceitos discriminatórios. Se o discurso de Joffrin aparenta conduzir o debate a proporções mais justas, não se deve esquecer de que ele participa de uma batalha virulenta no espaço público francês (basta citar os títulos das obras de Pascal Boniface, membro do Partido Socialista e polemista ativo sobre o assunto, “Est-il permis de critiquer Israël ?" [É permitido criticar Israel ?], e "La France malade du conflit israélo-palestinien" [A França doente pelo conflito israelense-palestino]. Essa discussão põe em evidência a questão bastante controversa da distinção a estabelecer entre crítica política legítima (tem-se o direito de criticar medidas políticas, ações governamentais, políticos, etc.) e procedimento de deslegitimação - ninguém tem o direito de negar os direitos do outro: seu direito de agir livremente, de se defender e o mais importante, o de existir. 
EID\&A - Revista Eletrônica de Estudos Integrados em Discurso e Argumentação, Ilhéus, n. 13, jan/jun.2017.

A esta acusação de deslegitimação, Joffrin se propõe a reagir. Ele retoma a distinção entre os "adversários encarniçados de Israel, que contestam não somente sua política, mas a sua própria existência", e "os detratores do governo Netanyahu, e principalmente nosso jornal que sempre defendeu, não somente a existência de Israel (o que é elementar) mas também seu direito à segurança". Com isso, ele faz uma redistribuição dos papéis a qual põe em causa o descrédito que BHL lançou a seu jornal e a ele mesmo - de um lado, o ódio aos judeus e o desejo de destruir seu Estado, do outro, os amigos que exercem seu direito de crítica. Essa redistribuição o obriga a adotar um tom que contrasta com o de BHL. Enquanto este fulmina e combate inimigos declarados, o diretor do Libération se coloca como crítico equilibrado e como amigo de Israel que reconhece sua legitimidade e seu direito à autodefesa. Ele chega a fustigar seus opositores. Por seu tom moderado, ele projeta um ethos de homem reflexivo e de bom conselheiro que rompe com a imagem passional construída por BHL em seu discurso veemente.

O mais importante é que ele opõe à acusação de deslegitimação a ideia de que a crítica exigente só se manifesta em relação às democracias e, com isso, não deslegitima Israel, mas, ao contrário, o legitima ao colocá-lo na categoria altamente valorizada dos países democráticos:

É a honra exigindo das democracias que sejam criticadas mais frequentemente e mais acirradamente que muitas ditaduras. Quantos artigos na imprensa democrática sobre Guantánamo, quantos sobre os métodos policiais em vigor nos regimes islâmicos? Há com certeza dois pesos e duas medidas. Mas isso finalmente é auspicioso: esse desequilíbrio mostra que a opinião democrática crê em seus próprios princípios e quer aplicá-los, primeiramente, a si mesma. Espera-se mais de uma democracia que de uma ditadura: é isso o que importa, e vale tanto para os bloqueios quanto para as abordagens de navios no mar. Abdicar dessas críticas em nome do realismo ou de uma equidade aparente, é solapar os fundamentos morais e políticos dos regimes de liberdade. Assim as críticas dirigidas à política do Estado hebreu pelos democratas não visam à sua deslegitimação. Ao contrário, esse debate aberto, mesmo sendo virulento, é um dos elementos constitutivos da legitimidade de Israel (grifos meus).

A inversão é notável e permite levar a polêmica para um movimento em que o país tão caro ao adversário aparece, paradoxalmente, elogiado: a crítica severa e as exigências elevadas para com o Estado hebreu contra as quais se manifesta BHL constituem, de fato, o reconhecimento do que faz sua glória sua democracia. A questão da legitimidade sofre, como se vê, um deslocamento. A legitimação outorgada não se aplica aos atos de Israel, nem à sua própria existência (que não precisa dela), ela concerne à natureza de seu 
EID\&A - Revista Eletrônica de Estudos Integrados em Discurso e Argumentação, Ilhéus, n. 13, jan/jun.2017.

regime político e aos valores que lhe são aferentes. Ora, “noblesse oblige"**... neste caso, obriga a aceitar os ataques, mesmo aqueles que são violentos e exasperam o intelectual, e a ver na crítica acerba uma homenagem.

Esse contra-argumento retoma também, à sua maneira, um dos pontos de dissensão que divide os pró-palestinos e os pró-israelenses. Esses últimos, efetivamente, se insurgem sempre contra a atitude de "dois pesos, duas medidas" que faz com que Israel seja vilipendiado e arrastado na lama, enquanto outros países que agem de maneira pior fiquem isentos de condenações e não provoquem reações passionais. BHL evoca que no Conselho de Direitos Humanos das Nações Unidas [...], encarregado de julgar Israel, "reinam os grandes democratas que são os cubanos, os paquistaneses e mais os iranianos". Ele vê nisso a prova irrefutável dos preconceitos em relação a Israel e a infração à regra de justiça que lhe impõem. Ora, Joffrin reinterpreta a questão baseando-se implicitamente na natureza particular da regra de justiça: ela demanda que se apliquem as mesmas medidas a instâncias similares em condições similares. Ora, não se trata, neste caso, de instâncias similares, mas justamente, como bem diz seu Oponente, de um país democrático de um lado e de países obscurantistas do outro. Desse modo, não se pode aplicar-Ihes a mesma regra, no caso, a mesma crítica, visto que esta se baseia em exigências ligadas a valores democráticos compartilhados.

Nessa breve troca nas páginas do Libération, que é apenas uma parte da polêmica contra BHL conduzida por outros jornalistas como Christophe Ayad (também no jornal Libération), Gidon Lévy (o jornalista israelense), ou ainda o socialista Pascal Boniface, pode-se ver como funciona uma polêmica no espaço público - e no caso em questão, no espaço público francês contemporâneo. Mesmo quando pretendem ter comportamentos reflexivos, os discursos se repercutem num choque de posições antagônicas.

Eles dicotomizam - a apresentação do bloqueio de Gaza é considerada impiedosa e ilegal por um, humana, legal e inevitável pelo outro, a ideia da crítica a Israel como deslegitimação é diametralmente oposta à da critica a Israel como legitimação; o argumento de "dois pesos, duas medidas" põe em choque a incriminação de injustiça e a distinção entre o joio e o trigo. Nesse debate contraditório, as paixões se inflamam e os axiológicos são abundantes, e acontecem ataques virulentos ao adversário, sempre desqualificado em suas

\footnotetext{
** N.T.: Expressão que, ao pé da letra, significa: "a nobreza obriga”. Refere-se ao comportamento que se espera de alguém que ocupa uma posição social elevada. Consultar: <http://stella.atilf.fr/Dendien/scripts/tlfiv5/search.exe?23;s=4127790825;cat=1;m=noblesse+oblige;>
} 
EID\&A - Revista Eletrônica de Estudos Integrados em Discurso e Argumentação, Ilhéus, n. 13, jan/jun.2017.

tomadas de posição políticas e éticas. Encontramos então uma polarização que opõe os defensores incondicionais de Israel e suas críticas severas, geralmente chamados de detratores. Entre esses dois grupos, reina uma tensão muito grande: de um lado, aqueles que veem, na condenação lançada contra Israel, ações de pró-palestinos e de judeófobos; do outro, aqueles que veem na defesa incondicional de Israel um comunitarismo cego mal visto na República.

Entretanto, as duas partes se falam e continuam a discutir, mesmo que a contextualização do debate revele, com frequência, uma repetição cansativa: são os mesmos argumentos e as mesmas oposições que se expressam sob diferentes óticas, a partir de novas circustâncias. A polêmica levou a um acordo? Certamente não. Desempenhou outras funções na praça pública? Provavelmente. Uma delas é persuadir aqueles que pensam como você. É o papel do epidítico: trata-se de reforçar uma identidade de grupo e uma adesão a um universo de valores comuns, que eventualmente acharão meios de se concretizar na ação. É uma função social não negligenciável. Mas não resultaria num diálogo de surdos, como pensa Marc Angenot (2002)? Não concordo com essa posição. $O$ que ocorre é que a polêmica enseja uma confrontação pública em que cada um dos dois campos pode expressar sua dissensão com base em valores comuns, que saem fortalecidos mesmo quando são diversamente interpretados: a democracia, a necessidade de uma crítica política racional, a regra de justiça, a condenação das atitudes de ódio. Ela permite aos dois campos opor-se como adversários que se reconhecem mutuamente o direito à livre expressão e à tentativa de conquistar a adesão do Terceiro, e não como inimigos que combatem com violência física. Essa transformação dos inimigos em adversários está no centro do pensamento da politóloga Chantale Mouffe (2000) que destaca sua importância num espaço democrático pluralista onde o conflito é a regra.

As opiniões, as crenças, os interesses, divergentes quando não contraditórios, que se produzem necessariamente no espaço público, devem encontrar aí o seu lugar. É nesse sentido que em meu livro, Apologie de la polémique [Apologia da polêmica] (2014), insisti na importância do desacordo na democracia, e na possibilidade de uma coexistência no dissenso que a polêmica pública proporciona4.

${ }^{4}$ Consulte-se também Amossy (2011). 
EID\&A - Revista Eletrônica de Estudos Integrados em Discurso e Argumentação, Ilhéus, n. 13, jan/jun.2017.

\section{Referências}

AMOSSY, Ruth. L’argumentation dans le discours. Paris: Colin, 2012 [2000].

. Faut-il intégrer l'argumentation dans l'analyse du discours? Problématiques et enjeux. Argumentation et Analyse du Discours [En ligne], n. 9, 2012. Disponível em: http://aad.revues.org/1346. Acesso em: 22 jul. 2015.

- La coexistence dans le dissensus. La polémique dans les forums de discussion. Semen, n. 31, p. 25-42, 2011.

ANGENOT, Marc. La parole pamphlétaire. Typologie des discours modernes. Payot: Paris, 1982.

. Doxa and cognitive breaks. Poetics Today, n. 23, v. 3, p. 513-537, 2002.

. Le dialogue de sourd. Traité de rhétorique antilogique. Paris: Mille et une Nuits, 2008.

ARISTOTE. Rhétorique. Traduction de Médéric Dufour. Paris: Gallimard, [s.d.].

DASCAL, Marcelo. Types of polemics and types of polemical moves. In: CMEJRKOVA, S. et al. (Éds). Dialogue Analysis. Tubingen: Max Niemeyer, 1998. p. 15-33.

. Dichotomies and types of debates. In: EEMEREN van, Frans H.; GARSSEN, Bart (Éds). Controversy and Confrontation. Amsterdam; Philadephia: Benjamins, 2008. p. 27-49.

GARAND, Dominique. Propositions méthodologiques pour l'étude du polémique. HAYWARD, Annette; GARAND, Dominique (Éds). États du polémique. Montréal: Nota Bene, 1998. p. 211-268

GELAS, Nadine. Étude de quelques emplois du mot 'polémique'. In: ; KERBRATORECCHIONI, Catherine (Éds). Le discours polémique. Lyon: Presses Universitaires de Lyon, 1980. p. 41-50.

KERBRAT-ORECCHIONI, Catherine. La polémique et ses définitions. In: GELAS, Nicole; (Éds). Le discours polémique. Lyon: Presses Universitaires de Lyon. 1980. p. 3-40.

KING, A. A.; ANDERSON, F. D. Nixon, Agnew and the Silent majority: A case study in the rhetoric of polarization. Western Speech, v. 35, n. 4, p. 243-255, 1971.

KOCK, Christian. Constructive controversy: rhetoric as dissensus-oriented discursoe. Cogency, n.1, v.1, p. 89-111, 2009.

KOREN, Roselyne. Stratégies et enjeux de la 'dépolitisation' du langage. In: DUBIED, Annik; GREVISSE, Benoît (Éds). Recherches en communication: La polémique journalistique. Louvain: Université Catholique de Louvain, 2003. p. 65-84. 
EID\&A - Revista Eletrônica de Estudos Integrados em Discurso e Argumentação, Ilhéus, n. 13, jan/jun.2017.

KRIEG-PLANQUE, Alice. La notion de "formule" en analyse du discours. Cadre théorique et méthodologique. Presses Universitaires de Franche-Comté, 2009.

MOUFFE, Chantal. The Democratic Paradox. London; New York: Verso, 2000.

ORKIBI, Eithan. Ethos collectif et Rhétorique de polarisation: le discours des étudiants en France pendant la guerre d'Algérie. Argumentation et Analyse du Discours, n. 1, 2008. Disponível em: http://aad.revues.org/438.

PLANTIN, Christian. Des polémistes aux polémiqueurs. In: DECLERCQ, G. et al. (Éds). La parole polémique. Paris: Champion, 2003. p. 377-408.

PERELMAN, Chaïm. The Rational and the Reasonable. In: The New Rhetoric and the Humanities. Essays on Rhetoric and its Applications. Dordrecht: Reidel, 1979. p. 117-123.

PERELMAN, Chaïm; OLBRECHTS-TYTECA, Lucie. Traité de l'argumentation. La nouvelle rhétorique. Bruxelles: Presses de l'Université de Bruxelles, 1970 [1958].

PHILLIPS, Kendall R. The spaces of public dissension: reconsidering the public sphere. Communication monographs, n. 63, p. 231-248, 1996.

Tradução:

Angela Maria da Silva Corrêa

Docente da Universidade Federal do Rio de Janeiro

Forma de citação sugerida:

AMOSSY, Ruth. Por uma análise discursiva e argumentativa da polêmica. Trad. Angela Maria da Silva Corrêa. EID\&A - Revista Eletrônica de Estudos Integrados em Discurso e Argumentação, Ilhéus, n. 13, p. 227-244, jan/jun.2017.

Recebido em: 31/05/2017

Aprovado em: 31/05/2017 